\title{
Private Label Management in Retail: the Concept, Consumer Profiling and Competition with National Brands. Systematic Review of Main Findings
}

In this theoretical article we are discussing the main aspects of private label management in retail. With growing importance of private labels in retail, this topic is being constantly addressed by researchers and brand managers, trying to highlight the main aspects of PL management and specifics of marketing. We explore and present research streams, discussing private label concept, profiling customers and depict the main aspects of competition between private labels and national brands. We define and explore each research stream and provide insights on successful private label management, which can be adapted both by private label and by national brands managers who are facing competition between these two types of brands.

Keywords: private label management, retail, consumer profiling, national brands.

Šiame teoriniame straipsnyje aptariame pagrindinius privataus prekès ženklo vadybos mažmeninëje prekyboje aspektus. Su augančia privačių prekès ženklų svarba mažmeninèje prekyboje, susidoméjimas šia tema auga tiek akademineje bendruomeneje, tiek verslo aplinkoje, stengiantis apibrèžti esminius privataus prekès ženklo vadybos principus ir rinkodaros ypatybes. Analizuojame ir pristatome esmines tyrimo sritis privataus prekès ženklo tyrimuose - privataus prekès ženklo koncepciją, vartotojų profiliavimą ir pagrindinius konkurencijos skirtumus tarp nacionalinių ir privačių prekès ženklų. Apibrěžiame ir tyrinèjame kiekvieną tyrimo sritị, pateikdami įžvalgas, vedančias link sèkmingos privataus prekès ženklo vadybos. Praktiniai straipsnio aspektai gali būti pritaikyti tiek privataus prekès ženklo vadyboje, tiek kitų prekès ženklų vadyboje, ypač prisitaikant konkurencineje aplinkoje tarp šių dviejų prekès ženklų rǔšių.

Raktiniai žodžiai: privataus prekès ženklo vadyba, mažmeninè prekyba, vartotojų profiliavimas, nacionaliniai prekès ženklai.

\section{Introduction}

Private labels (PLs) are brands owned by retailers and sold exclusively in their stores (Bushman, 1993; DeWulf et al., 2005) being part of retailers' business. The importance of PLs in retailers' strategic decisions is emerging. The relevance of $\mathrm{PL}$ management as a research topic is identified by top retail journals, indicating that

Indrè BRAZAUSKAITĖ - ISM Vadybos ir ekonomikos universiteto doktorantè. Adresas: Arklių g. 18, Vilnius. E. paštas: indre.brazauskaite@stud.ism.lt.

Viltè AURUŠKEVIČIENĖ - socialinių mokslų daktarè, ISM Vadybos ir ekonomikos universiteto profesorè. Adresas: Arklių g. 18, Vilnius. E. paštas: vilaur@ism.lt.

Rima GERBUTAVIČIENĖ - dr., Lietuvos sveikatos mokslų universiteto docentè. Adresas: Eivenių g. 12, Kaunas. E. paštas: rima.gerbutaviciene@lsmuni.lt. 
private label strategy issues are the key areas of research priorities in retail area (Puccinelli et al., 2009; Grewal and Levy, 2009, 2007; Grewal et al., 2004; Ailawadi and Keller, 2004). Grewal and Levy (2007) and Grewal et al. (2004) indicate that understating the process how buyers make the decision when choosing private label products and what makes the value for these buyers are still emerging issues. K. L. Ailawadi and K. L. Keller (2004) remark that even if there is a lot of data regarding consumer behavior in retail and consumer behavior towards private labels, it is not quite clear what exactly makes the private label success.

Starting from exclusive "value for money" offer that was an initial purpose of these brands, lately the concept has broadened dramatically. Many international retailers now perceive the adoption and diffusion of PLs to be one of their foremost priorities (Baltas and Argouslidis, 2007) which makes private label management an emerging trend in retail business and discussed topic among scientific contributors to retail management. Private labels or store brands have become important part of retailers' business due to the value it is able to offer - fortunate private labels give retailers such benefits as store differentiation, store loyalty, enhances the brand, contributes to traffic building and capturing higher market share (Burt and Sparks, 2002; Ailawadi, Gedenk and Nelsin, 2001; Corstjens and Laj, 2000; Richardson, 1997). PLs often generate higher profit margins for the retailer and at the same time offer customers fair prices for products similar to other brands in market (Hoch and Banjeri, 1993), PLs impose strong competitive threats against national brands (Ailawadi and Keller, 2004; Karry and Zaccour, 2006) which increases retailers bargaining power and contributes to gaining stronger position in market.

Following the benefits, private labels are lately introduced by more and more retailers and tend to span increasing number of categories and penetrate at much greater pace than manufacturers' brands (Baltas and Argouslidis, 2007; Lincoln and Thomassen, 2008). For these reasons the strategic importance of PL brands is getting more significant for retailers at the same time being a more relevant threat for owners of manufacturers' brands. The private label management topic becomes critically important for both parties - retailers and manufacturers and the need of strategic and tactical marketing activities adaptation to presence of PLs urges.

Retailers meet a challenging task how to create a private label strategy that meets consumers' value expectations? There the question appears - what should retailers do for private labels to succeed? Brand managers face a challenge as well how to foresee development of private labels and how to react to retailers' private labels? What brand strategy should be adapted when facing competition with private labels?

This paper explores the nature and development of private labels and its competition with national brands, having the aim to review the most important aspects of private label management in retail, discussing works of the most important research contributors to the conceptualization and management of the private label.

We indicated the major research streams, focusing on private label management and raised the objectives, which allow us to unveil the conceptualization of private label: 
1. Discuss the concept of private labels and its development.

2. Reveal private labels' customers' profile.

3. Indicate the most important aspects of rivalry between private labels and national brands.

Focusing on the purpose of this particular paper which intends to reveal the main aspects of private label management in retail, we are presenting a systematic review of main findings in the area. Methodology, used in this paper is of analytical nature we are reviewing, analyzing and presenting main theoretical findings that focus on the topic we chose with intention to review the main findings and ideas in this area and providing insights in the area.

\section{The concept of private labels}

National (manufacturers' owned) and private label (retailers' owned) brands are two types of retail brands that differ substantially in the nature of management, strategy and tactics. N. Kumar and J. Steenkamp (2007), acknowledged as being the most important contributors to private label management, indicate that private labels do not follow the same strategy pattern as brands do; these brands differ from national brands in many core elements of the marketing mix, including branding, labeling, price, distribution and level of advertising. The core task for private label strategy to be successful is to stimulate private label purchase intention over all other brands in retail assortment, especially over leading brands that often become a benchmark for PLs as these adopt a "me too" strategy (Grill, 2010; Ahuwalia and Burnkrant, 2004; Pechmann, 1996). Retailers are often using copycat strategy to grow PLs while manufacturers' brands are forced to enter the competition and adapt their strategies according the competitive situation in markets.

The competitive environment for growing private labels and national brands becomes more challenging as retailers are pushing own brands, seeking benefits that fortunate PLs are able to offer - store differentiation and loyalty, brand enhancing and traffic building (Burt and Sparks, 2002; Ailawadi, Gedenk and Nelsin, 2001; Corstjens and Laj, 2000; Richardson, 1997). Use of PL concept in retail is contributing to caption higher market share, generating higher profit margins for the retailer and at the same time offering customers fair prices for products similar to other brands in the market (Hoch and Banjeri, 1993). PLs impose strong competitive threats against national brands (Ailawadi and Keller, 2004; Karry and Zaccour, 2006). Introduction of private labels is an obvious benefit for retailers, but impose a threat for manufacturers' brands as these activities increase rivalry not only on the retailers' shelves but in the market as well.

We indicate the main retailers' value sources the private labels provide (Cuneo et al., 2012; Alintas, Kilic and Senol, 2010; Baltas and Argouslidis, 2007), becoming an important part of retailers' business:

1. Strategic benefits and role of private labels, such as improvement of store image, loyalty and differentiation (Ailawadi et al, 2008; Corstjens and Laj, 2002; Burt, 2000) which strengthens retailer's position in the market by offering unique value proposition for customers, shopping at particular retail chain.

2. Increased revenues, providing superior margins compared to manufacturer brands (Ailawadi and Harlam, 
2002; Hoch and Banjeri, 1993). D. Puri and K. De (2012) indicate that retailers' gross margins on private labels are usually 25 to 30 percent higher compared to national brands. This benefit helps to improve overall profitability and generate increased income by pushing own PLs.

3. Increased bargaining power over manufacturers (Gomez and Benito, 2008; Pauwels and Srinivasan, 2002; Farris and Ailawadi, 1992). Having strong PL products in assortment, retailers are able to compete with leading brands or delist the ones that are substitutable. This leads retailers to more efficient assortment as demand for some brands in assortment is decreasing.

4. Reactivation and expansion of stagnant categories (Scott and Zettelmeyer, 2004; Hauser and Shugan, 1983). Not having successful products in some categories may limit such categories' turnover and share, therefore by adding PLs to such categories retailers create growth and development by themselves with no need of external suppliers or brand developers.

Lately retailers started to increase investments into PLs which led to a tendency of increasing perceived quality level of retail. Factors, such as qualitative products' innovation, application of sophisticated packaging, adaptation of various pricing practices and widening assortment started to appear (Kumar and Steenkamp, 2007) which increased value perception for PLs, creating increased trust in these brands and provoking a more intense rivalry between private labels and national brands. Even though we observe private labels growth in market (Kumar and Steenkamp, 2007), K. De Wulf et al. (2005) contrarily argue that majority of customers continue to prefer national (branded) products over retailers' brands. C. G. Mieres et al. (2006) and P. S. Richardson et al. (1994) indicate that the main reason behind is that despite private labels development is still perceived as being inferior and low-quality compared to branded products. Private labels are often treated as second-role alternatives to branded products, even if it is a growing segment. Retailers meet a challenging task - how to make private label strategy meeting consumers' value expectations which leads to higher investments in this product group development.

\section{Profiling private label consumers}

Private label consumers' evolution overcame some development stages that can be noticed in researchers' works. We could define several streams of literature that are capturing private label consumer profiling, starting from demographic issues, finishing with the latest trend towards personality profiling and psychographics, indicating that consumer behavior towards PLs have been changing across these brands development with many authors focusing their work on consumer behavior related to private labels (Baltas, 2003; Batra and Sinha, 2000; Corstjend and Laj, 2000; Sinha and Batra, 1999; Baltas et al, 1997).

Early studies of private labels focused on their buyers demographics (Grazin, 1981), being the main trigger for choosing these products. Later these finding were confirmed by O. E. Omar (1996) indicating that differences between demographic characteristics of consumers who prefer private labels and the ones preferring branded products exist. A recent stu- 
dy by D. Puri and K. De (2012) confirms that private labels are rarely chosen by young consumers. Contrarily, P. Shukla et al. (2013) revealed positive correlation of private label proneness and younger customers, with lower-education group, at the same time with increasing interest of high-income customers to private labels. It is found that the level of education has impact when choosing PL products. P. S. Richardson et al. (1996) reveals that higher level of education leads to less private label brand proneness. S. Burton et al. (1998), on the contrary, found that consumers having higher level of education demonstrate higher level of private labels proneness. Even though demographic issues are important to consider, researchers (Slama and Tashchian, 1985; Shukla et al., 2013) agree that different stages of demographics make different shopping decisions, therefore, more factors should be considered.

The focus on socio-economic issues emerged after the demographics-related studies. P. S. Richardson et al. (1996) indicate that income level, family size and education correlated to proneness to private labels - consumer with higher income demonstrated lower interest in private labels, confirming R. E. Frank and H. J. W. Boyd (1965) findings that lower income consumers more often purchase private labels because of financial pressures. Young families, for example, more often choose private labels, which might be related to financial situation of young families and request of brand engagement that exist within younger customers.

Consumer behavior studies show that buyers of private label brands are price sensitive (Ailawadi, Gedenk and Neslin, 2001; Richardson et al., 1996). Price remains an important trigger for private label choice during the last decades. It was revealed (Hoch, 1996; Sivakurmar and Raj, 1997) that lower-income customers tend to be less loyal to brand compared to higher-income customers, and this behavior results in search of value offer that PLs are able to offer.

Stream, focusing on socio-economic factors of private label buyers evolved into emphasis of psychographic issues, related to PL choice. Psychographic consumer profiling was able to offer more complex insights into PL proneness. A study done by G. Baltas and P. C. Argouslidis (2007) explains that spending per trip, monthly expenditure, family size, gender and age were not highly significant in the purchase of private labels, showing that different context affects the purchase intention which can be evaluated in a narrowed demographic or socio-economic manner, suggesting that the concept of private labels become more and more spilled over different demographic and socio economic groups.

Later on, researchers began studying individual personalities in terms of purchase intention motivation (Cantor, 1990). H. Baumgartner (2002) argued that it might be useful to analyze personality profiling in terms of Big Five taxonomy according to labeled personality dimensions. S. Whelan and G. Davies (2006) notice an ongoing interest in personality profiling for private label users. These authors were studying personality profiling and its link to private label purchase intention. The taxonomy they used enabled to reveal if different types of consumer's characteristics are related to purchasing different types of products. It also revealed that consumer behavior depends on personality dimensions. They showed that extroverts are more prone to 
national brands, as ambitions and sociability plays important role in choosing national brands (Whelan and Davies, 2006) because social affiliation needs to be satisfied. S. Whelan and G. Davies (2006) found that in low involvement categories private labels are bought more often than in high involvement. Private label products could be referred to openness to experience; these customers are willing to try new offerings. National brands could be referred to extrovert profile, followed by ambition and sociability. Many authors found that private label buyers focus on price and value consciousness (Burton et al., 1998; Batra and Sinha, 2000; Ailawadi et al., 2001) and tend to be more deal prone comparing to users of national brands (Burton et al., 1998; Ailawadi et al., 2001). J. A. Garretson et al. (2002) found that consumer self-perception was positively related to attitudes toward private labels and to subsequent purchase intentions. According to K. L. Ailawadi et al. (2001), J. A. Garretson et al. (2002) and P. Shukla et al. (2013) private label buyers consider themselves as smart shoppers that are being loyal to a brand. S. Burton et al. (1998) found that when private labels become attractive to consumers, their loyalty to national brands decreases. D. Puri and K. De (2012) define attractiveness of private labels with concepts of perceived quality, price, trust and packaging. This reveals that private label consumers are becoming more diverse and their behavior is influenced by complex factors which needs further investigation.

At the initiation of private label concept, researchers focused on demographic profiling of private label buyers (Granzin, 1981), socioeconomic profiling (Frank, 1967) with later emphasis on profiling private label buyers' personalities (Baum- gartner, 2002; Whelan and Davies, 2006). G. Baltas et al. (1997) indicate that attitudinal and behavioral characteristics appear to be better predictors of the proneness to buy private labels than demographics as it was revealed that private label buyers tend to spread across all demographic and socio-economic groups (Burger and Schott, 1972) and this trend is getting more and more evident nowadays, as purchase intention is often linked to attitudinal and behavioral issues. Historically private labels buyers' behavior was differentiated from national brands buyers on the assumption that each buyer chose their preferred type of brand and would not switch to another type, e.g. private label buyer would stick to private label, not branded products. W. Gordan (1994) argued that on some shopping occasions consumers prefer private labels and on another - national brands, therefore different levels of purchase involvement could define different patterns for consumer behavior which lead to constant competition between private labels and national brands.

\section{Competition between private labels and national brands}

In all retail chains a strong competition between private labels and national brands exists, being one of the most important topics in brand management in retail. Both brand managers and retailers' focus their efforts on consumers' willingness to choose one brand over another. Researchers (Olson, 2012; Dursun et al., 2011; Ailawadi et al., 2001; Burt, 2000; Aggarawal and Cha, 1998; Narasimhan and Wilcox, 1998; Baltas et al., 1997; Richardson et al., 1994) explore the differences in management 
and competition between national brands and private labels, making this topic one of the main research streams in private label management. As already mentioned, N. Kumar and J. Steenkamp (2007) argue that private labels do not follow the same strategy pattern as brands do; these brands differ from national brands in many core elements of the marketing mix, including branding, labeling, pricing, distribution and level of advertising, therefore, competition is becoming more complex.

Retailers often adopt a copycat approach for their private labels on which the strategy is frequently built, weakening national brands' position in the channel. Practices, such as imitating packaging, value pricing proposition for similar products, aggressive merchandizing and in-store marketing are common for PLs to adapt. However, owners of national brands, facing this type of competition are urged to apply certain strategies which should be more difficult to copy.

According to E. L. Olson (2012), private label packaging often closely resembles the leading manufacturers' brand, therefore positively relates to inferences that the two brands are more similar in specifications. Use of similar packaging provokes a thought that the two brands are identical in specification and for this reason private labels are often chosen impulsively. A combination of copied packaging and merchandizing (when similar packages are placed next to each other) tend to have a more powerful impact for impulsive buying. Consumers are provoked to accidently mix similar products and choose PLs over branded products. E. L. Olson (2012) indicates that the "concept of comparison" is very strong in private label strategy - messages, inviting to compare private labels with national brands positively relate to inferences that the two brands are more similar in specifications or that brand leader is the source of PL. Comparisons are stronger than the copycat condition, suggesting personality and attitude measures to increase the frequency of consumer misidentification of private labels as manufacturer brands while increasing positive consumer evaluations of the copier (Ailawadi and Keller, 2004; Rafiq and Collins, 1966).

As private labels and national brands do not follow the same marketing strategy, it is clear that PLs usually focus on low-marketing expenses while national brands usually have much bigger marketing support, resulting in investment in products' development, enhancement of brand image and engagement, and creation of loyalty. Additional marketing expenses affect pricing, causing wide price differences between private labels and branded products (Quelch and Harding, 1996; Corstjens et al., 1995). The image of branded products is usually built via advertising. According to P. C. Verhoef et al. (2002), advertising investments of branded products are much higher compared to private labels. It is already clear that advertising creates brand awareness and can positively affect consumers' willingness to purchase a particular brand or product (Mackenzie and Lutz, 1989). S. J. Hoch and S. Banjeri (1993) and R. L. Steiner (2004) found that advertising quantity of branded products can be an obstacle to the increasing market share of private labels. Increase in national brand's advertising volume causes decrease of private labels market share. Insufficient advertising can lead private labels to improper familiarity that may form a negative attitude, therefore retailers are searching for additional possibilities to 
increase awareness. We notice that retailers often exploit in-store marketing possibilities, rather than activities that demand higher marketing budgets. Recent studies (Dursun et al., 2011) show that brand familiarity plays the most important role in promoting customers purchase intention. High level of consumer familiarity is required for increased private labels success. According to I. Dursun et al. (2011) and A. Dick et al. (1995), familiarity can be increased by strengthening the advertising and promotional campaigns, price deals, using in-store displays, informational material at the point of purchase, product aisles and offering samples in the store. As brand familiarity is equal to sales value, retailers usually use in-store promotions, though $\mathrm{K}$. De Wulf et al. (2005) and S. Levy and H. Gendel-Guterman (2012) argues that retailers should invest in private labels promotion to build a strong and sustainable brand. Private labels usually get the premium places in shopping areas as retailers control merchandising. M. G. Brown and J. Lee (1996) indicate that shelf space might be considered as a form of advertising, putting products on the top of consumers' minds, and generally suggesting products popularity level - shelf space can even affect demand by reducing consumer search cost. Nogales and Suarez (2005) indicate that by giving more shelf space for particular brand increases its visibility and consequently the probabilities of it being purchased. Retailers typically make comparisons by placing private labels next to the targeted national brands (Grill, 2010) which refers to enhancing credibility and invitation to compare (Friestad and Wright, 1994; Pechmann, 1996). According to G. Baltas et al. (1997) price difference between private labels and branded products is an essential issue to attract customers and generate sales. Therefore the advantage of in-store marketing becomes an option, very often adopted by retailers. Retailers use PLs as value offer and motivate consumers to notice it. Main findings, concerning private label pricing issues is the value offer (Ailawadi, Gedenk and Nelsin, 2001; Richardson et al., 1996), making the price one of the most important drivers for choice. Because of imitation strategy, private labels are usually 15 to 40 percent cheaper than national brands (Ashley, 1998) which invites consumer to compare brands and to be value-conscious.

The main competitive differences between private labels and national brands could be defined as marketing expenses, pricing, merchandizing and promoting differences. Understanding the key differences between private labels and national brands may lead to understanding consumer behavior that leads to brand rejection. Since private labels usually follow leading brands in their marketing efforts, it is important to compare these brands in research as well.

\section{Conclusions and recommendations}

It is noticeable that the authors define private labels as an emerging issue in retail sector since these brands are becoming increasingly important to retailers for the benefits they offer - strategic gains, as increased loyalty, enhanced image and store differentiation; and financial gains, as increased revenues and superior margins, which altogether increases retailers' bargaining power.

Following the contribution of benefits to retailer, private label research can be characterized as one of the key research issues 
in retail. We determine three main streams in private label research - exploration of private label concept and benefits of these brands, specifics of private labels' rivalry with branded products and studies, related to consumers' profiling and behavior. With earlier studies' towards private label consumer profiling and behavior, we indicate a tendency in recent works revealing that consumers become "smart shoppers" and often choose private label products because of looking for value purchase options. Therefore, demographic differentiation cannot be adapted as a strategy anymore. Further investigation should be done in the area of consumer behavior towards private labels, taking into account different shopping occasions and different behavior when choosing products from different categories.
Private label strategy is very often much related to retailer's strategy. We indicate that private labels often adopt copycat strategy which is supported by marketing activities that do not demand high marketing expenses, such as in-store advertising, premium merchandizing and competitive pricing. Concept of comparison is often used to highlight similarities with national brands and enhance the value proposition that private labels are able to propose.

In conclusion, it is important to draw attention towards the research of private label development, which demands further investigation in a more detailed way, capturing actual consumer behavior in different situations. We propose more case studies and experiments to be employed in private label research.

\section{References}

1. Aggarwal, P., Cha, T. (1998). Asymmetric price competition and store versus national brand choice // Journal of Product and Brand Management. Vol. 7, No. 3, pp. 244-253.

2. Ahuwalia, R., Burnkrant, R. E. (2004). Answering questions about questions: a persuasion knowledge perspectivefor understanding the effects of rhetorical questions // Journal of Consumer Research. Vol. 31, No. 6, pp. 26-42.

3. Ailawadi, K. L., Borin, N., Farris, P. W. (1995). Market power and performance: a cross industry analysis of manufacturers and retailers // Journal of Retailing. Vol. 71, No. 3, pp. 211-248.

4. Ailawadi, K. L., Gedenk, K., Neslin, S. A. (2003). Understanding competition between retailers and manufacturers: an integrated analysis of store brand and national brand deal usage. Working Paper No. 03-16, Tuck School of Business at Dartmouth, Hanover.

5. Ailawadi, H., Harlam, B. (2002). The effect of store brands on retailer profitability: an empirical analysis. - Working Paper No. 02-6, Tuck School of Business at Dartmouth, Hanover.
6. Ailawadi, K. L., Keller, K. L (2004). Understanding retail branding: conceptual insights and research priorities // Journal of Retailing. No. 80, pp. 331-342. doi: 10.1016/j.jretai.2004.10.008.

7. Ailawadi, K. L., Neslin, S.A., Gedenk, K. (2001). Pursuing the value- conscious consumer: store brands versus national brand promotions // Journal of Marketing. Vol. 65, No. 1, pp. 71-89.

8. Ailawadi, K., Pauwels, K., Steenkamp, J. B. (2008). Private label use and store loyalty // Journal of Marketing Vol. 72, No. 11, pp. 19-30.

9. Altintas, M. H., Kilic, S., Senol, G., Isin, F. B. (2010). Strategic objectives and competitive advantages of private label products // International Journal of Retail and Distribution Management. Vol. 38, No. 10, pp. 773-788. doi:10.1108/09590551011076542.

10. Ashley, S. R. (1998). How to effectively compete against private-label brands // Journal of Advertising Research. Vol. 38, No. 1, pp. 79-83.

11. Baltas, G. (2003). A combined segmentation and demand model for store brands // European Journal of Marketing. Vol. 37, No. 10, pp.1499-1513.Doi:10.1108/03090560310487211. 
12. Baltas, G. (1997). Determinants of store brand choice: a behavioral analysis // Journal of Product and Brand Management. Vol. 6, No. 5, pp. 315-324. Doi:10.1108/09590550710743708.

13. Baltas, G., Argouslidis, P. C. (2007). Consumer characteristics and demand for store brands // International Journal of Distribution and Management. Vol. 35, No. 5, pp. 328-341. doi: 10.11 08/09590550710743708.

14. Baltas, G., Doyle, P., Dyson, P. (1997). A model of consumer choice for national versus private label brands source // Journal of Operational Research Society. Vol. 48, No. 10, pp. 988-995.

15. Batra, R., Sinha, I. (2000). Consumer-level factors moderating the success of private label brands // Journal of Retailing. Vol. 76, No. 2, pp. 175-191.

16. Baumgartner, H. (2002). Toward a personology of the consumer // Journal of Consumer Research. Vol. 29, No. 2, pp. 286-292.

17. Brown, M. G., Lee, J. (1996). Allocation of shelf space: a case study of refrigerated juice products in grocery stores // Agribusiness. Vol. 12, No. 2, pp. 113-121.

18. Burger, P. C., Scott, B. (1972). Can private brand buyers be identified? // Journal of Marketing Research. Vol. 9, No. 3, pp. 219-222.

19. Burt, S. (2000). The strategic role of retail brands in British grocery retailing // European Journal of Marketing. Vol. 34, No. 8, pp. 875-890.

20. Burt, S., Sparks, L. (2002). Corporate branding, internationalization and the retailer as a brand // Corporate Reputation Review. Vol. 5, No. 2/3, pp. 194-212.

21. Burton, S., Lichenstein, D. R., Netemeyer, R. G., Garretson, J.A. (1998). A scale for measuring attitude toward private label products and an examination of its psychological and behavior correlates // Journal of the Academy of Marketing Science. Vol. 26, No. 4, pp. 293-306. doi: 10.1177/0092070398264003.

22. Bushman, B. J. (1993). What's in a name? The moderating role of public self-consciousness on the relation between brand label and brand preference // Journal of Applied Psychology. Vol. 78, No. 5, pp. 857-861.

23. Cantor, N. (1990). From thought to behavior: "having" and "doing" in the study of personality and cognition // American Psychologists. Vol. 45, No. 6, pp. 735.

24. Corstjens, J., Corstjens, M., Laj, R. (1995). Retail competition in the fast moving consumer goods industry: the case of France and UK // European Management Journal. Vol. 13, No. 4, pp. 636-673.
25. Corstjens, M., Laj, R. (2000). Building store loyalty through private labels // Journal of Marketing Research. Vol. 37, pp. 281-291.

26. Cuneo, A., Lopez, P., Yague, M. R. (2012). Private label brands: measuring equity across consumer segments // Journal of Product and Brand Management. Vol. 21, No. 06, pp. 428-438. doi: 10.1108/10610421211264919.

27. De Wulf, K., Odekerken-Schroder, G., Goedertier, F., Van Ossel, G. (2005). Consumer perceptions of store brands versus national brands // Journal of Consumer Marketing. Vol. 22, No. 4, pp. 223-232. doi: 10.1108/07363760510 605335.

28. Dick, A., Jain, A., Richardson, P. (1995). Correlates of store brand proneness: some empirical observations // The Journal of Product and Brand Management. Vol. 4, No. 4, pp. 8-15.

29. Dursun, I., Kabadayi, E. T., Alan, A. K., Bulent, S. (2011). Store brand purchase intention: effects in risk, quality, familiarity and store brand shelf space // Procedia Social and Behavioral Sciences. Vol. 24, pp. 1190-1200. doi: 10.1016/j.sbspro.2011.09.133.

30. Farris, P., Ailawadi, K. (1992). Retail power: monster or mouse? // Journal of Retailing. Vol. 68, No. 4, pp. 351-369.

31. Frank, R. E. (1967). Correlates of buying behavior for grocery products // Journal of Marketing. Vol. 31, No. 10, pp. 48.

32. Frank, R. E., Boyd, H. J. W. (1965). Are privatebrand-prone grocery customers really different? // Journal of Advertising Research. Vol. 5, No. 4, pp. 27-35.

33. Friestad, M., Wright, P. (1994). The persuasion knowledge model: how people cope with persuasion attempts // Journal of Consumer Research. Vol. 21, No. 6, pp. 1-31.

34. Garretson, J. A., Fisher, D., Burton, S. (2002). Antecedents of private label attitude and national brand promotion attitude: similarities and differences // Journal of Retailing. Vol. 78, No. 2, pp. 91-99.

35. Gomez, M., Benito, N. R. (2008). Manufacturer's characteristics that determine the choice of producing store brands // European Journal of Marketing. Vol. 42, No. 1/2, pp. 154-177. doi: 10.1108/03090560810840952.

36. Gordan, W. (1994). Retailer brands-the value equation for success in the 90's // Journal of market research society. Vol. 36, No. 3, pp. 165-181. 
37. Granzin, K. (1981). An investigation of the market for generic products // Journal of Retailing. Vol. 57, No. 4, pp. 30-55.

38. Grewal, D., Levy, M. (2009). Emerging Issues in Retailing Research // Journal of Retailing. Vol. 85, No. 4, pp. 522-526. doi: 10.1016/j.jretai.2009.09.007.

39. Grewal, D., Levy, M. (2007). Retailing research: Past, present and future // Journal of Retailing. Vol. 83, No. 4, pp. 447-464. doi: 10.1016/j.jretai.2007.09.003.

40. Grewal, D., Levy, M., Lehmann, D. R. (2004). Retail Branding and Loyalty: An Overview // Journal of Retailing. Vol. 80, No. 4, pp. 447-464. doi: $10.1016 /$ j.retai.2004.10.002.

41. Grill, J. (2010). Combating germs // Private label Magazine. Prieiga per internetą: <http://www. privatelabelmag.com/issues/pl-jan-2010/otc. cfm> [Accessed: 2014.05.01].

42. Hauser, J., Shugan, S. (1983). Defensive marketing strategies // Marketing Science. Vol. 2, No. 4, pp. 319-360.

43. Hoch, S. J. (1996). How should national brands think about private labels? // Sloan Management Review. Vol. 37, pp. 89-102.

44. Hoch, S. J., Banjeri, S. (1993). When do private labels succeed? // Sloan Management Review. Vol. 34, No. Summer, pp. 57-67.

45. Karry, S., Zaccour, G. (2006). Could co-op advertising be a manufacturer's counterstrategy to store brands? // Journal of Business Research. Vol. 59, No. 9, pp. 1008-1015.

46. Kumar, N., Steenkamp, J. (2007). Private label strategy: how to meet the store brand challenge. - Harvard Business Press.

47. Levy, S., Gendel-Guterman, H. (2012). Does advertising matter to store brand purchase intention? A conceptual framework // Journal of Product and Brand Management. Vol. 21, No. 2, pp. 89-97. doi: 10.1108/10610421211215418.

48. Lincoln, K., Thomassen, L. (2008). Private label: turning the retail brand threat into your biggest opportunity. - London: Kogan Page Publishers.

49. Mackenzie, S. B., Lutz, R. J., Belch, G. E. (1986). The role of attitude toward the ad as a mediator of advertising effectiveness: a test of competing explanations // Journal of Marketing Research. Vol. 23, No. 2, pp. 130-143.

50. Mieres, C. G., Martın, A. M. D., Gutierrez, J. A. T. (2006). Influence of store brand perceived risk on store brand proneness // International Journal of Retail \& Distribu- tion Management. Vol. 34, No. 10, pp. 761-72. doi: 10.1108/09590550610691347.

51. Narasimhan, C., Wilcox, R. T. (1998). Store brands and the channel relationship: a crosscategory analysis // Journal of Business. Vol. 71, No. 4, pp. 573-600.

52. Nogales, A. F., Suarez, M. G. (2005). Shelf space management of private labels: a case study in Spanish retailing // Journal of Retailing and Consumer Services. Vol. 12, pp. 205-216.

53. Olson, E. L. (2012). Supplier inferences to enhance private label perceptions // Journal of Business Research. Vol. 65, pp. 100-105. doi: 10.1016/j.jbusres.2011.02.2004.

54. Omar, O. E. (1996). Grocery purchase behavior for national and own label brands // The Service Industries Journal. Vol. 16, No. 1, pp. 58.

55. Pauwels, K., Srinivasan, S. (2002). Who benefits from store brand entry? // Marketing Science. Vol. 23, No. 3, pp. 964-990. doi:10.1287/ mksc.1030.0036.

56. Pechmann, C. (1996). Do consumers over generalize one-sided comparative prices claims, and are more stringent regulations needed? // Journal of Marketing Research. Vol. 33, pp. 150-162.

57. Puccinelli, M., Nancy, C., Goodstein, R., Grewal, D., Price, R., Ranghubir, P., Stewart, D. (2009). Consumer Experience Management in Retailing: Understanding the Buying Process // Journal of Retailing. Vol. 85, No. 1, pp. 15-30. doi: 10.1016/j.retai.2008.11.003.

58. Puri, D., De, K. (2012). Consumer preferences towards private labels - a study in Delhi // The Business and Management Review. Vol. 2, No. 1, pp. 192-204.

59. Rafiq, M., Collins, M. (1996). Lookalikes and customer confusion in the grocery sector: an exploratory survey // International Review of Retail Distribution Consumer Research. Vol. 6, No. 10, pp. 329-350.

60. Richardson, P. S. (1997). Are store brands perceived to be just another brand? // Journal of Product and Brand Management. Vol. 6, No. 6, pp. 388-404.

61. Richardson, P. S., Jain, A. K., Dick, A. (1996). Household store brand proneness: a framework // Journal of Retailing. Vol. 72, No. 2, pp. 159-185.

62. Richardson, P. S., Dick, A. S., Jain., A. K. (1994), Extrinsic and intrinsic cue effects on perceptions of store brand quality // Journal of Marketing. Vol. 58, No. 10, pp. 28-36. 
63. Scott, F, Zettelmeyer, F. (2004). The strategic positioning of store brands in retailer-manufacturer negotiations // Review of Industrial Organization. Vol. 24, No. 2, pp. 161-194.

64. Sinha, I., Batra, R. (1999). The effect of consumer price consciousness on private label purchase // International Journal of Research in Marketing. Vol. 16, pp. 237-251.

65. Sivakumar, K., Raj, S. P. (1997). Quality tier competition: how price changes influences brand choice and category choice // Journal of Marketing. Vol. 61, No. 3, pp. 71-84.

66. Slama, M.E., Tashchian, A. (1985). Selected socioeconomic and demographic characteristics associated with purchasing involvement // Journal of Marketing. Vol. 49, No. 1, pp. 72-82.

67. Shukla, P., Banerjee, M., Adidam, P. T. (2013). The moderating influence of socio-demographic factors on the relationship between consumer psychographics and the attitude towards private label brands // Journal of Consumer Behavior. Vol. 12, pp. 423-435. doi: 10.1002/cb.1441.

68. Steiner, R. L. (2004). The Nature and Benefits of National Brand/Private Label Competition // Review of Industrial Organization. Vol. 24, pp. 105-127.

69. Verhoef, P. C., Nijssen, E. J., Sloot, L. M. (2002). Strategic relations of national brand manufacturers towards private labels: an empirical study in The Netherlands // European Journal of Marketing. Vol. 36, No. 11/12, pp. 1309-1326. Doi: 10.1108/03090560210445191.

70. Quelch, J. A., Harding, D. (1996). Brands versus store brands: fighting to win // Harvard Business Review. Vol. 74, No. 1, pp. 99-109.

71. Whelan, S., Davies, G. (2006). Profiling consumers of own brands and national brands using human personality // Journal of Retailing and Consumer Services. Vol. 13, pp. 393-402. doi:10.1016/j.jretconser.2006.02.004.

The paper submitted: August 14, 2014 Prepared for publication: September 04, 2014

\section{Indrẻ BRAZAUSKAITĖ, Viltė AURUŠKEVIČIENĖ, Rima GERBUTAVIČIENÉ}

\section{PRIVATAUS PREKĖS ŽENKLO VADYBA MAŽMENINĖJE PREKYBOJE: KONCEPCIJA, VARTOTOJŲ PROFILIS, KONKURENCIJA SU NACIONALINIAIS PREKIŲ ŽENKLAIS. SISTEMINĖ TYRIMŲ APŽVALGA}

S a n t r a u k a

Privačių prekès ženklų segmentas mažmeninèje prekyboje yra vienas iš labiausiai augančių bei sulaukiančių dèmesio tiek iš akademinès bendruomenès, tiek iš verslo sektoriaus. Remiantis M. Puccinelli et al. (2009), D. Grewal ir M. Levy, (2009, 2007), D. Grewal et al. (2004) bei K. L. Ailawadi and K. L. Keller (2004), privataus prekès ženklo vadybos tyrimai priskiriami prie mažmeninès prekybos organizacijų tyrimų prioritetų. Privataus prekès ženklo vadyba neapsiriboja produktų grupés vadyba, o tampa viena esminių mažmeninès prekybos įstaigų strategijos dalimi dèl organizacijų vadybos plataus potencialo. Sèkmingi privatūs prekès ženklai mažmenininkams padeda diferencijuoti save tarp kitu prekybos kanalų ir stiprinti prekès ženklą, skatina vartotojų lojalumą bei padeda pritraukti didesnius vartotojų srautus, stiprindami mažmenininko poziciją rinkoje (Burt ir Sparks, 2002; Ailawa- di, Gedenk ir Nelsin, 2001; Corstjens ir Laj, 2000; Richardson, 1997).

Šiame teorinio pobūdžio straipsnyje aptariami esminiai privataus prekès ženklo (angl. private label) vadybos principai mažmenineje prekyboje. Straipsnio autoriai išskiria tris pagrindines tyrimų sritis, susijusias su privataus prekès ženklo vadyba - privataus prekès ženklo koncepcijos vystymąsi, pagrindinius konkurencijos su kitais prekès ženklais aspektus bei tyrimus, nagrinëjančius vartotojų elgsenos ypatumus renkantis šio tipo prekès ženklo produktus. Aptariamos minètos tyrimų šakos, apibendrinant esminius tyrimus jose, bei pateikiamos įžvalgos, analizuojančios mažmeninès prekybos sektorių - tiek privataus prekès ženklo produktus, tiek nacionalinius prekes ženklus (angl. national brands).

Šio straipsnio tikslas yra apžvelgti pagrindinius privataus prekès ženklo vadybos aspektus mažmenineje prekyboje, aptariant ir analizuojant svar- 
biausius tyrèjų darbus šioje srityje. Autoriai išskyrẻ pagrindines tyrimų šakas, susijusias su privataus prekès ženklo vadyba ir suformulavo šiuos uždavinius:

1. Aptarti privataus prekès ženklo koncepciją ir jos vystymąsi.

2. Atskleisti privataus prekès ženklo vartotojų profili.

3. Identifikuoti pagrindinius konkurencijos aspektus tarp privačių ir nacionalinių prekès ženklų rinkoje.

Metodologija. Siekiant straipsnio užsibrèžto tikslo, autoriai apžvelgia tyrimus, analizuojančius pagrindinius privataus prekès ženklo vadybos aspektus. Pristatoma sisteminè literatūros analizè, analizuojami ir pristatomi tyrèjų darbai, pateikiami apibendrinimai ir pateikiamos ǰžvalgos. Remiantis tyrimo rezultatais, galima išskirti temos aktualumą ir augančią svarbą mažmeninès prekybos sektoriuje tiek iš akademinès bendruomenès, tiek iš verslo sektoriaus. Tema reikalauja daugiau tyrimų, stebint vartotojų elgseną specifinèse situacijoje. Autoriai rekomenduoja plačiau taikyti tokius tyrimo metodus kaip atvejo analizė arba eksperimentas, kurie leistų detaliau ištirti šią sritị. 